
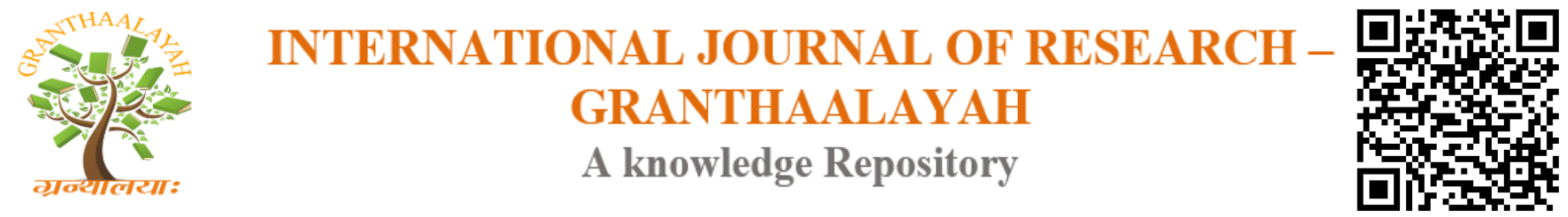

Science

\title{
KRUMIROGA: LITERARY REVIEW
}

\section{Dr. Pragati Y. Chougule ${ }^{1}$, Dr. Sujata P. Jadhav ${ }^{2}$}

${ }^{1}$ P.G. Scholar, Department of Kayachikitsa, Y.A.C.P.G.T \& R.C, Kodoli, Kolhapur, India

${ }^{2}$ Guide, Assistant Professor, Department of Kayachikitsa, Y.A.C.P.G.T \& R.C, Kodoli, Kolhapur, India

\begin{abstract}
Krumi is an important disease described in ayurvedic science and is described in detail with respect to its etiology, clinical features and treatment. The term krumi is used to denote tiny organisms which reside in human body. Concept of krumi and their relation in the development of disease is described in almost all ayurvedic samhita. Acharyas also describe krumi as an etiological factor in various diseases. Krumi contribute significantly to global burden of diseases. Overcrowding, contamination of water, poor sanitation greatly favour transmission of parasitic infection resulting in high endemicity. Intestinal worm infestation results in impaired nutrition. Many neglect this condition as most of the times it may be asymptomatic. It maybe associated with malnutrition, iron deficiency anaemia, repeated gastrointestinal disturbances and upper respiratory tract infections.
\end{abstract}

Keywords: Krumi; Organisms; Parasitic Infection; Impaired Nutrition; Gastrointestinal Disturbances.

Cite This Article: Dr. Pragati Y. Chougule, and Dr. Sujata P. Jadhav. (2017). "KRUMIROGA: LITERARY REVIEW." International Journal of Research - Granthaalayah, 5(10), 168-174. https://doi.org/10.29121/granthaalayah.v5.i10.2017.2293.

\section{Introduction}

Krumi is a serious public health problem and is widely prevalent in areas of low environmental quality and people of low nutritional status. In India, the problem is likely to be more common because of bad hygiene, poor awareness, illiteracy, poverty and variety of allied factors. The term krumi as mentioned in ayurvedic classics have broad meaning. It includes all types of macro and micro, pathogenic and non-pathogenic organism. In classical text alongwith vata, pitta, kapha, sukshma jantu are also supposed to be responsible for creating disease. Description regarding the management of krumi is available since vedic period.

\section{Nirukti of Krimi}

“Kramati Kramu Pada Vikshepe. ”(Halayudh kosha, page -242) 
The term "Krumi" is derived from the word 'Kramu', meaning to step/ to roam/ or to walk. It has come out from "Kramu Padvikshepe", meaning - move with the legs; are termed as Krumi.

\section{“Kramau Kshudra-jantou, Rogabhede Krimi Shabde”.(Amarkosha)}

According to Amarkosha Krimi word is derived from "Kram + en" which denotes Kshudra-jantu and in differentiation of Rogas.

\section{“Lumpayanti Kida Krimayah Paritah" (Vachaspatyam $3{ }^{\text {rd }}$ part)}

It means those which are capable to break or injure the surroundings can be said as Krumi.

\section{Classification}

Acharya Charak classified Krumi into two groups i.e. a) Sahaja and b) Vaikarika.

\section{1) Sahaja Krumi}

Also called as avaikarik krumi. They live in human body right from birth till death and are not harmful to human body. They are numerous in number and live in the buccal cavity, alimentary tract as well as in vaginal canal of female as a normal bacterial flora.

\section{2) Vaikarika Krumi}

They are exactly opposite to sahaja krumi and are pathogenic in nature. They cause disease or deformity in body.

Vaikarika krumi are classified into two subgroups - 1.Bahya krumi (external) and 2. Abhyantara Krumi (internal). Those krumi which live on the skin outside the body are bahya krumi and those inside the body are abhyantara krumi.

Acharya Charak and Vagbhat have mentioned bahya krumi while Acharya Sushrut has not mentioned bahya krimi. Acharya Sushrut has classified abhyantar krumi in two groups (i) Drishya and (ii) Adrishya. According to Sushrut Sleshmaja and Purishaja Krumi are drishya and Raktaja krumi are adrishya.

According to Charak and Vagbhat krumi are classified as - 1) Raktaja 2) Kaphaja 3) Purishaja and 4) Malaja.

Total no. of Krumi according to various acharyas

\begin{tabular}{|l|l|l|}
\hline Sr. no. & \multicolumn{1}{|c|}{ Texts } & Number \\
\hline 1. & Charak samhita & 20 \\
\hline 2. & Harita Samhita & 13 \\
\hline 3. & Bhela Samhita & 20 \\
\hline 4. & Sushruta Samhita & 20 \\
\hline 5. & Ashtanga Sangraha & 20 \\
\hline 6. & Madhava Nidanam & 20 \\
\hline 7. & Sharangadhara & 22 \\
\hline
\end{tabular}




\begin{tabular}{|l|l|l|}
\hline & Samhita & \\
\hline 8. & Bhav Prakash & 20 \\
\hline
\end{tabular}

Classification of krumi -

\begin{tabular}{|l|l|l|l|l|l|l|l|}
\hline \multirow{2}{*}{ Number } & \multirow{2}{*}{ Name } & \multirow{2}{*}{$\begin{array}{c}\text { Bahya } \\
\text { Krumi }\end{array}$} & & \multicolumn{5}{|c|}{ Abhyantar Krumi } & Total \\
\cline { 5 - 9 } & & & Total & Kaphaja & Purishaja & Raktaja & \\
\hline 1. & Charak & 2 & 18 & 7 & 5 & 6 & 20 \\
\hline 2. & Harita & 7 & 6 & & & & 13 \\
\hline 3. & Bhela & & & & & & 20 \\
\hline 4. & Sushruta & & 20 & 6 & 7 & 7 & 20 \\
\hline 5. & Vagbhata & 2 & 18 & 7 & 5 & 6 & 20 \\
\hline 6. & Madhavkara & 2 & 18 & 7 & 5 & 6 & 20 \\
\hline 7. & Sharangdhar & $2+1$ & $18+1$ & 7 & 5 & 6 & 22 \\
\hline 8. & Bhavamishra & 2 & 18 & 7 & 5 & 6 & 20 \\
\hline
\end{tabular}

All Acharyas except Acharya Harit and Acharya Sharangdhar have mentioned total 20 types of krumi. Acharya Harit has described 7 types of bahya krumi and 6 type of abhyantara krumi while Acharya Sharangdhar has described total 22 Krumi with the addition of 2 Krumi - a)Snayuka and b)Vrana krumi each.

Names of Krumi given by different acharyas

Bahya krumi -

\begin{tabular}{|l|l|l|l|}
\hline No. & Charak & Sushrut & Vagbhat \\
\hline 1. & Yuka & --- & Yuka \\
\hline 2. & Pipillika & --- & Leeksha \\
\hline
\end{tabular}

Abhyantar krumi -

It includes kaphaja, purishaja and raktaja krumi.

Kaphaja krumi -

\begin{tabular}{|l|l|l|l|}
\hline No. & Charak & Sushrut & Vagbhat \\
\hline 1. & Antrada & Mahapushpa & Antrada \\
\hline 2. & Hrudayada & Praloona & Hridayada \\
\hline 3. & Udarada & Chipita & Udarveshtha \\
\hline 4. & Churu & Pipillika & Churu \\
\hline 5. & Mahaguda & Daruna & Mahakuha \\
\hline 6. & Saugandhika & & Sugandha \\
\hline 7. & Darbhakusuma & Darbhapushpa & Darbhakusuma \\
\hline
\end{tabular}


Purishaja krumi -

\begin{tabular}{|l|l|l|l|}
\hline No. & \multicolumn{1}{|c|}{ Charak } & \multicolumn{1}{c|}{ Sushrut } & \multicolumn{1}{c|}{ Vagbhat } \\
\hline 1. & Kakeruka & Ajava & Kakeruka \\
\hline 2. & Makeruka & Vijava & Makeruka \\
\hline 3. & Sausurada & Kipya & Sausurada \\
\hline 4. & Sashulak & Chipya & Saluna \\
\hline 5. & Leliha & Gandupad & Leliha \\
\hline 6. & & Churu & \\
\hline 7. & & Dwimukhaha & \\
\hline
\end{tabular}

Raktaja Krumi -

\begin{tabular}{|l|l|l|l|}
\hline No. & \multicolumn{1}{|c|}{ Charak } & \multicolumn{1}{c|}{ Sushruta } & \multicolumn{1}{c|}{ Vagbhat } \\
\hline 1. & Keshad & Keshada & Keshada \\
\hline 2. & Lomad & Romada & Lomavidhvamsa \\
\hline 3. & Lomadwipa & Nakhada & Lomadwipa \\
\hline 4. & Saurasa & Dantada & Saurasa \\
\hline 5. & Udumbara & Kikkisha & Udumbara \\
\hline 6. & Jantumatra & Kushtaja & Matraha \\
\hline 7. & & Parisarpaja & \\
\hline
\end{tabular}

According to Acharya Charak, krumi have their specific habitat. Bahya krumi are usually found on the external part of the body such as hair, over the scalp and body, beard, eyelashes or clothes. Raktaja krumi dwell in the vessels carrying blood. Shleshmaja krumi are usually found in amashaya which have tendency to move upward or downward along the intestinal tract. Purishaja Krimi are in pakawashaya which usually migrate downward towards the rectum and anus. Rarely they may travel towards the stomach resulting in fecal smelled belching and breathing.

\section{Nidanpanchak of krumi}

\section{Nidan}

\section{1) Bahya krumi}

According to Acharya Charak, Vagbhat, Madhavakar, Bhavaprakash and Vangasen bahya krumi are caused due to unhygienic and dirty habits (Mrijavarjanam). Harita refers to its origin from sweat, dryness (of skin and or body) and worry (Yuka and Liksha).

\section{2) Abhyantara krumi}

Aahara - consumption of food even during ajirna; intake of excess madhur, amla and lavana rasa; excess intake of liquids; pishtayukta aahara; excess intake of masha, patrashaka, tila kalka.

Specific factors - excess intake of mamsa, dugdha, dadhi, shuktha, guda, satthu, yava etc.

Vihara - lack of vyayama, divaswap

Acharya Charaka has said that nidan of purishaja krumi is same as nidan of sleshmaja krumi while Acharya Charak and Vagbhat has mentioned that nidan of raktaja krumi is same as kustha nidan. 
As per observations, nidan like excess intake of mamsa, patrashaka etc.help in the ingestion of ova and cyst into human body. Nidan like diwasvapa, ajirnashan, asatmya, virudha bhojana etc. create agnimandya and a favourable atmosphere in the koshtha for the growth of krumi and diet like green vegetables (patrashaka), pishtanna, godhuma etc. create major bulk of faeces. According to dalhana this accumulation of faeces gives favourable environment for the growth of krumi as they are originating from the vapours of faecal matter.

\section{Samprapti}

1) Dosha - kapha dominant tridosha

2) Dushya - rasa, rakta

3) Srotasa - Mahasrotasa, Purishvaha Srotasa, Raktavaha Srotasa

4) Adhisthana -

Bahya krumi- kasha, twak, vastra

Kaphaja krumi- Amashaya; Purishaja krumi - Pakwashaya; Raktaja krumi - Raktavaha Dhamani.

According to acharya Sushrut the vitiated kapha dosha and pitta dosha by any of the hetu of krumiroga, may help in production of krumi. Most of the factors described in the etiology of krumiroga lead to agnimandya and amothpatti which work as the principle factor in the process of samprapti and leads to production of krumi.

\section{Rupa}

Clinical feature of krumi vary with the nature of the krumi and part of organ affected by them.

Bahya krumi- kandu, kotha, pidaka, ganda.

Abhyantara krumi- jwara, vivarnata, shula, hridroga, bhrama, bhaktatidwesha, atisara, sadana, chhardi, shwasa, vami, mandagni, jathar garjanam, pipasa, pitanetra.

\section{Upashaya and anupashaya}

Pathya and apathy of krumiroga are mentioned by acharya Harita, Kashyapa, Sushruta and in Bhaisajya Ratnavali.

\section{Pathya in krumiroga}

Shodhankarma like snehan, swedan, asthapana basti, shirovirechan, virechan, dhumpan; Consumption of Nimba, Arka (White), Karela, Koshataki, Rakta shali, Tila, Sarshapa, Kulaththa, Yava, Mudga, Gomutra, Madhu, Sura, Sukta, Sauvira, Tushodaka, Patola, Rasona, Chitraka, Kantakari, Vidanga, Haritaki, Bhallataka, Hingu, Ajamoda, Khadira, Devadaru, Shunthi; avoidance of worry. 


\section{Apathya in krumiroga}

Vamana vegavidharana, diwaswapna, ajeerna, excess consumption of mamsa, dugdha, patrashaka, viruddha bhojan, dadhi, guda, pishtamaya padartha, masha, amla rasa and madhura rasayukta padartha.

\section{Chikitsa}

\section{1) Management of krumiroga in vedas}

In vedas various type of krumighna drugs are described. In Atharvaveda, krumighna dravya are described in three categories - krumi jambhana (retarding the activity), kruminashana (inhibiting the growth of krumi) and krumighna (killing the krumi). Apart from this, worship of agni and surya are said to destroy krumi. Most of krumighna effect come under devavyapasraya chikitsa.

\section{2) Management of krumiroga in samhita.}

In charak vimansthana $7^{\text {th }}$ chapter, charak has mentioned three main theories for treatment of Krimi Roga -

"Sarvakriminamapakarshanaamevaaditah karya, tatah prakrutivighatah, anantaram nidanoktanam bhavanamanupasevanamiti ||" (ch.vi.7/4)

i. Apakarshan- Apakarshan means to scratch the dosha, mala and krumisanghata forcefully. Any process by which the unwanted elements are removed or extracted from the body is considered as apakarshana. Krumi residing inside the body should be expelled out by the administration of appropriate shodhana karma - vamana, virechana, shirovirechana and asthapana basti.

ii. Prakrutivighata- Prakrutivighata means destruction of the producing/favourable environment. To counteract the factors responsible for production of krumi, dravya which are katu, tikta, kashaya in taste; kshara and ushna in nature should be used alongwith other drugs having properties contrary to purisha and kapha. Any measure successful against the infestation and reinfestation of krumi should be considered under prakrutivighata.

iii. Nidanaparivarjana- Nidanaparivarjana means to eliminate the causative factors which help in producing, germinating and growing of krumi. Hence, factors responsible for production of krumi should be avoided. Nidanparivarjana is most important principle as ayurveda gives importance to aahara, vihara as treatment. They stress over hygiene and body resistance than the infection. All unhygienic substances and lifestyle modifications conclude under nidan of krumi.

\section{Discussion}

Krumi i.e. helminths or worms are remarkable among samkramika ghatakas (infectious agents). The term krumi as mentioned in ayurvedic classics have broad meaning. It includes all types of macro and micro, pathogenic and non-pathogenic organism. In classical text alongwith vata, pitta, kapha, sukshma jantu are also supposed to be responsible for creating disease. Description regarding the management of krumi is available since vedic period. Helminthic infestations contribute significantly to global burden of diseases, especially in tropical and sub-tropical 
regions. Krumi have large variation in size, complex life cycle and migratory habits within their host and these account for an estimated billion infections each year.

\section{Conclusion}

Description of krumi and krumiroga is available in vedas, samhitas and other literature but according to time era depth of literature varies considerably. Acharyas have classified krumi as sahaja and vaikarika which specifies that they were also aware about non pathogenic nature of krumi (commensal). Sleshmaja krumi live in upper part of gastrointestinal tract while purishaja krumi is live in lower part of gastro intestinal tract and survive on feacal matter. Raktaja krumi dwell in blood vessels. It is difficult to correlate ayurvedic terms regarding krumi with modern term due to lack of detail description of each krumi. Acharya Charak has mentioned three folded treatment of krimi roga (i)Apakarshana (ii) Prakrutivighata and (iii) Nidan parivarjan.

\section{References}

[1] Charak samhita Vol 1, Vd Brahmanand Tripathi, Chaukhamba prakashan, Reprint 2014.

[2] Sushrut samhita Vol 2, Vd Ambikadatta Shastri, Chaukhamba prakashan, Reprint 2013.

[3] Ashtang Hridayam, Vd. Brahmanand Tripathi, Chaukhamba prakashan, Reprint 2009.

[4] Madhav Nidan Vol 1, Vd. Yadunandopadhya, Chaukhamba prakashan, Reprint 2008.

[5] Yogratnakar, Vd. Lakshmipati Shastri, Chaukhamba prakashan, Reprint 2009.

[6] Bhavaprakash, Vd. Bhavashankar Mishra, Chaukhamba prakashan, Reprint 2010.

*Corresponding author.

E-mail address: prgti.3006@ gmail.com 